\title{
KAJIAN VARIANCE MEAN RATIO PADA SIMULASI SEBARAN DATA BINOMIAL NEGATIF*
}

\author{
Choirun Nisa ${ }^{1}$, Muhammad Nur Aidi ${ }^{2 \ddagger}$, and I Made Sumertajaya ${ }^{3}$
}

\author{
1'Department of Statistics, IPB University, Indonesia, choirun_nisa@apps.ipb.ac.id \\ 1Department of Statistics, IPB University, Indonesia, nuraidi18081960@gmail.com \\ 1'Department of Statistics, IPB University, Indonesia, imsjaya.stk@gmail.com \\ Fcorresponding author
}

Indonesian Journal of Statistics and Its Applications (elSSN:2599-0802)

Vol 4 No 4 (2020), 615 - 626

Copyright ( 2020 Choirun Nisa, Muhammad Nur Aidi, and I Made Sumertajaya. This is an openaccess article distributed under the Creative Commons Attribution License, which permits unrestricted use, distribution, and reproduction in any medium, provided the original work is properly cited.

\begin{abstract}
The negative binomial distribution is one of the data collection counts that focuses on success and failure events. This study conducted a study of the distribution of negative binomial data to determine the characterization of the distribution based on the value of Variance Mean Ratio (VMR). Simulation data are generated based on negative binomial distribution with a combination of $p$ and $n$ parameters. The results of the VMR study on negative binomial distribution simulation data show that the VMR value will be smaller when the $p$-value is large and the VMR value is more stable as the sample size increases. Simulation data of negative binomial distribution when $p \geq 0.5$ begins to change data distribution to the distribution of Poisson and binomial. The calculation VMR value can be used as a reference for detecting patterns of data count distribution.
\end{abstract}

Keywords: negative binomial distribution, over dispersion, variance mean ratio.

\section{Pendahuluan}

Terdapat hal dasar yang perlu diketahui sebelum melakukan analisis statistika, yakni terkait sebaran suatu data. Hal ini penting dipahami untuk menentukan langkah yang tepat dalam menangani dan menganalisis suatu data yang ada. Berdasarkan ruang sampelnya, sebaran peluang suatu data dibagi menjadi dua, yaitu sebaran data kontinu dan data diskrit (Ahdika, 2015). Data diskrit atau data cacah hanya dapat

\footnotetext{
${ }^{\star}$ Received Jul 2020; Accepted Des 2020; Published online on Des 2020
} 
berupa nilai-nilai tertentu (bilangan bulat). Sebaran data cacah atau diskret yang memusatkan pada kejadian sukses dan gagal yakni meliputi sebaran bernouli, sebaran binomial, sebaran geometrik, sebaran poisson, dan sebaran binomial negatif. Pola dasar sebaran suatu data dibagi menjadi tiga kelompok yaitu sebaran acak (random), sebaran yang mengelompok (aggregated) dan sebaran seragam (uniform) (Krebs, 2013) .

Setiap data pengamatan perlu diketahui pola sebaran supaya analisis yang digunakan hasilnya valid. Mengetahui pola sebaran data terdapat beberapa metode yang dapat digunakan. VMR (Variance Mean Ratio) merupakan metode paling sederhana untuk menentukan pola sebaran suatu data. Nilai VMR diperoleh dari perhitungan rasio antara nilai varians contoh dengan nilai rata-rata contoh yang disebut juga sebagai indeks dispersi (I). Suatu data mengkuti sebaran Poisson atau acak, jika varians contoh sebanding dengan rata-rata contoh atau nilai I berada pada kisaran angka 1; ketika rasio kurang dari 1 atau mendekati 0 menunjukkan data mengikuti sebaran seragam; dan saat rasio lebih dari 1 menunjukkan pola sebaran datanya mengelompok atau binomial negatif (Krebs, 2013).

Jika nilai VMR atau indeks dispersi suatu data pengamatan lebih besar dari satu, maka model yang digunakan dikatakan mengalami overdispersi (Hilbe, 2014). Overdispersi merupakan kondisi yang nilai varians lebih besar dari nilai tengahnya atau $\operatorname{Var}(X)>E(X)$. Dalam praktek di lapangan, data cacah sering mengalami overdispersi. Data yang mengalami overdispersi menyebabkan galat baku menjadi terlalu rendah (underestimate), sehingga pengambilan keputusan menjadi tidak tepat Salah satu altenatif pemodelan yang dapat mengakomodasi kondisi overdispersi yakni regresi binomial negatif dengan data yang menyebar binomial negatif (Molla \& Muniswamy, 2012)

Sebaran binomial negatif berlawanan dengan sebaran binomial. Sebaran peluang binomial menghitung banyaknya keberhasilan dalam banyaknya percobaan yang tetap sedangkan sebaran peluang binomial negatif menghitung banyaknya percobaan yang diperlukan untuk melihat banyaknya keberhasilan yang tetap (Baron, 2014). Sebaran binomial negatif merupakan sebaran yang dapat mengakomodasi hubungan antara sebaran lainnya (Inuwa, 2013). Setiap sebaran data memiliki karakteristiknya masing-masing. Penelitian ini dikembangkan evaluasi kecocokan pola sebaran melalui simulasi data sebaran binomial negatif berdasarkan nilai VMR. Studi simulasi ini dilakukan untuk mengetahui karakteristik sebaran binomial negatif setiap kondisi bangkitan data simulasi.

\section{Metodologi}

\subsection{Bahan dan Data}

Data simulasi dibangkitkan berdasarkan sebaran binomial negatif dengan berbagai parameter data yaitu $\boldsymbol{p}(0.1,0.2,0.3,0.4,0.5,0.6,0.7,0.8,0.9)$ dan ukuran contoh $\boldsymbol{n}$ $(10,50,100)$. Kajian simulasi data meliputi 288 kondisi dengan berbagai kombinasi parameter $\boldsymbol{p}$ dan $\boldsymbol{n}$ yang telah ditetapkan. Karateristik sebaran binomial negatif dilihat berdasarkan pola sebaran data secara deskriptif, nilai VMR dan pengujian kecocokan sebaran melalui uji khi kuadrat. 


\subsection{Metode Penelitian}

Kombinasi dari parameter data simulasi masing-masing diulang sebanyak seratus kali. Data simulasi dibangkitkan berdasarkan sebaran binomial negatif melalui tahap-tahap berikut:

1. Membangkitkan data yang menyebar binomial negatif dengan kombinasi parameter $\boldsymbol{p}$ dan $\boldsymbol{n}$ yang sudah ditetapkan dengan perulangan sebanyak seratus kali.

2. Melakukan eksplorasi terhadap data yang telah dibangkitkan menggunakan histogram dan grafik untuk mengetahui karakteristik dari sebaran data melalui perubahan nilai $\boldsymbol{p}$ dan $\boldsymbol{n}$.

3. Menghitung rata-rata nilai VMR pada setiap kombinasi parameter data bangkitan.

4. Mengeksplorasi dan menganalisis rata-rata nilai VMR data bangkitan berdasarkan perubahan nilai $\boldsymbol{p}$ dan $\boldsymbol{n}$.

5. Melakukan pengujian kecocokan sebaran data bangkitan dengan uji khi kuadrat serta analisis nilai VMR untuk mengetahui perubahan sebaran data cacah yang dibangkitkan.

6. Kesimpulan terkait karakteristik sebaran data yang telah dibangkitkan berdasarkan hasil uji kecocokan sebaran dan rata-rata nilai VMR.

\section{Hasil dan Pembahasan}

\subsection{Perbandingan Matematis Nilai VMR}

Jika X menyatakan berapa kali terjadi keberhasilan dalam $n$ ulangan bebas, yang masing-masing berpeluang $p$ untuk sukses dan $1-p$ untuk gagal, maka X dinamakan peubah acak binomial dengan parameter $(n, p)$. Fungsi massa peluang bagi suatu peubah acak binomial dituliskan pada persamaan (1) dengan $x=1,2, \ldots, n$ dan $0 \leq$ $p \leq 1$ (Casella \& Berger, 2001). Nilai tengah dan nilai ragam sebaran binomial yakni $\mu=\mathrm{E}(\mathrm{X})=n p$ dan $\operatorname{Var}(X)=n p(1-p)$, diperoleh nilai VMR pada persamaan (2).

$$
\begin{aligned}
& \mathrm{P}(\mathrm{X}=x)=\left(\begin{array}{l}
n \\
x
\end{array}\right) p^{x}(1-p)^{n-x} \\
& V M R=\frac{\operatorname{Var}(\mathrm{X})}{\mathrm{E}(\mathrm{X})}=\frac{n p(1-p)}{n p}=(1-p)=q<1
\end{aligned}
$$

Banyaknya hasil percobaan yang terjadi selama selang waktu atau daerah tertentu disebut percobaan Poisson (Walpole, 2007). Fungsi peluang sebaran poisson ditunjukkan pada persamaan (3) dengan $x=0,1,2, \cdots$. Nilai tengah dan nilai ragam sebaran Poisson yakni $\mu=\mathrm{E}(X)=\lambda$ dan $\operatorname{Var}(X)=\lambda$, sehingga diperoleh nilai VMR pada persamaan (4).

$$
\begin{aligned}
& \mathrm{P}(\mathrm{X}=x)=\mathrm{e}^{-\lambda} \frac{\lambda^{x}}{x !} \\
& \operatorname{VMR}=\frac{\operatorname{Var}(X)}{\mathrm{E}(\mathrm{X})}=\frac{\lambda}{\lambda}=1
\end{aligned}
$$


Jika peubah acak X menyatakan banyaknya percobaan yang diperlukan hingga terjadi $r$ keberhasilan, maka sebaran probabilitas peubah acak X disebut sebaran binomial negatif dan fungsi peluangnya ditunjukkan pada persamaan (5) dengan $x=$ $r,(r+1), \cdots$.

$$
\mathrm{P}(\mathrm{X}=x)=\left(\begin{array}{l}
x-1 \\
r-1
\end{array}\right) p^{r}(1-p)^{x-r}
$$

Sebaran binomial negatif merupakan sebaran yang memiliki banyak cara pendekatannya. Penurunan klasik dari sebaran binomial negatif yakni $y$ menyatakan banyaknya kegagalan sebelum terjadi $r$ sukses. Sehingga fungsi massa peluang dapat dituliskan pada persamaan (6) dengan $y=0,1,2, \ldots$ dan nilai tengah dan ragamnya masing-masing yakni $E(Y)=\frac{r(1-p)}{p}$ dan $\operatorname{Var}(Y)=\frac{r(1-p)}{p^{2}}$ (Hilbe, 2011). Sehingga diperoleh perhitungan nilai VMR pada persamaan (7).

$$
\begin{aligned}
& \mathrm{P}(\mathrm{Y}=y)=\left(\begin{array}{c}
y+r-1 \\
r-1
\end{array}\right) p^{r}(1-p)^{y} \\
& V M R=\frac{\operatorname{Var}(Y)}{E(Y)}=\frac{r(1-p)}{p^{2}} \times \frac{p}{r(1-p)}=\frac{1}{p}>1
\end{aligned}
$$

Hasil perbandingan perhitungan matematis nilai VMR pada ketiga sebaran ditunjukkan pada Tabel 1 dengan interval 0 sampai lebih besar dari 1.

Tabel 1: Perbandingan Matematis Nilai VMR.

\begin{tabular}{llc}
\hline Binomial & Poisson & Binomial Negatif \\
\hline$V M R=(1-p)=q<1$ & $V M R=\frac{\lambda}{\lambda}=1$ & $V M R=\frac{1}{p}>1$
\end{tabular}

Sebaran binomial negatif mengalami overdispersi dengan ditandai nilai VMR lebih besar dari 1. Kondisi ini menunjukkan pada sebaran binomial negatif cenderung mempunyai variansi yang lebih besar daripada sebaran data cacah lainnya. Perhitungan matematis VMR pada sebaran binomial negatif menunjukkan VMR berbanding terbalik dengan $p$ yang berarti bahwa ketika nilai $p$ semakin kecil maka nilai VMR semakin besar.

\subsection{Eksplorasi Data Simulasi}

Data yang telah dibangkitkan dengan berbagai kombinasi parameter $\boldsymbol{p}$ dan $\boldsymbol{n}$ dieksplorasi menggunakan histogram untuk mengetahui kondisi data cacah dari sebaran binomial negatif. Nilai $\boldsymbol{p}$ yang ditampilkan adalah $0.1,0.3,0.5,0.7$, dan 0.9 untuk masing-masing ukuran contohnya 10,50 dan 100. 

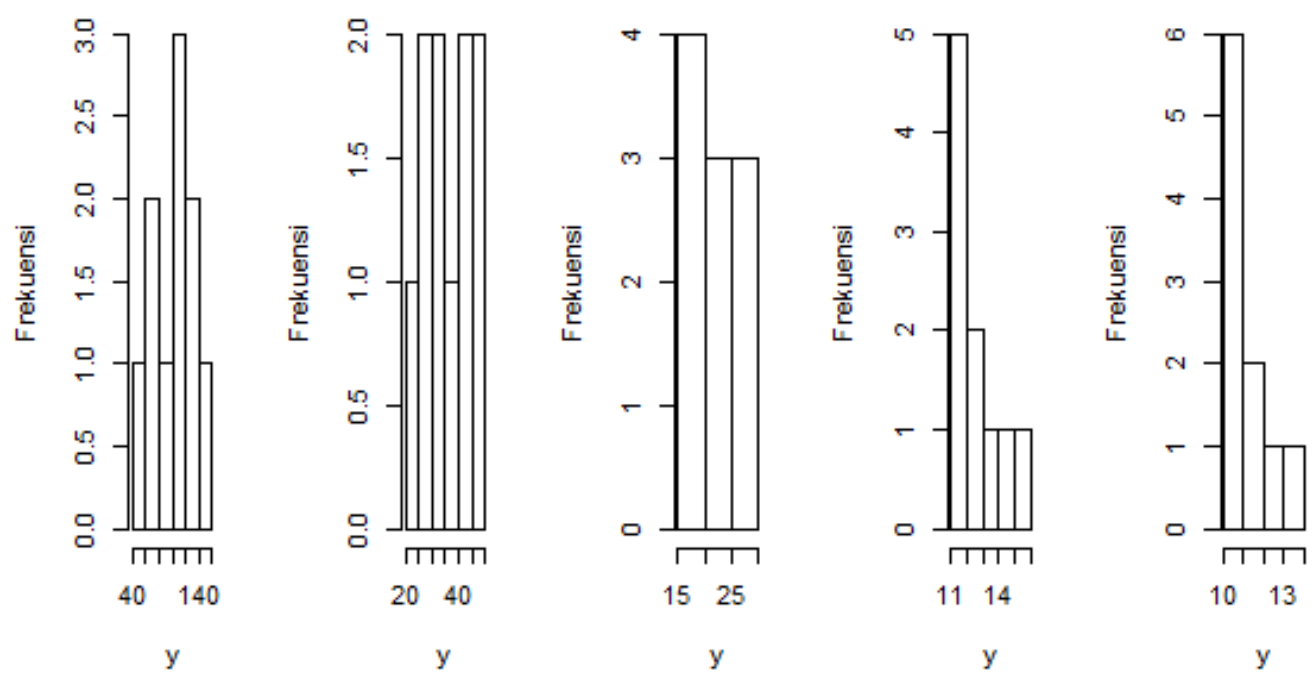

(a) $p=0.1$

(b) $p=0.3$

(c) $p=0.5$

(d) $p=0.7$

(e) $p=0.9$

Gambar 1: Histogram data pada $n=10$ dengan $(a) p=0.1,(b) p=$ $0.3,(c) p=0.5,(d) p=0.7$, dan $(e) p=0.9$
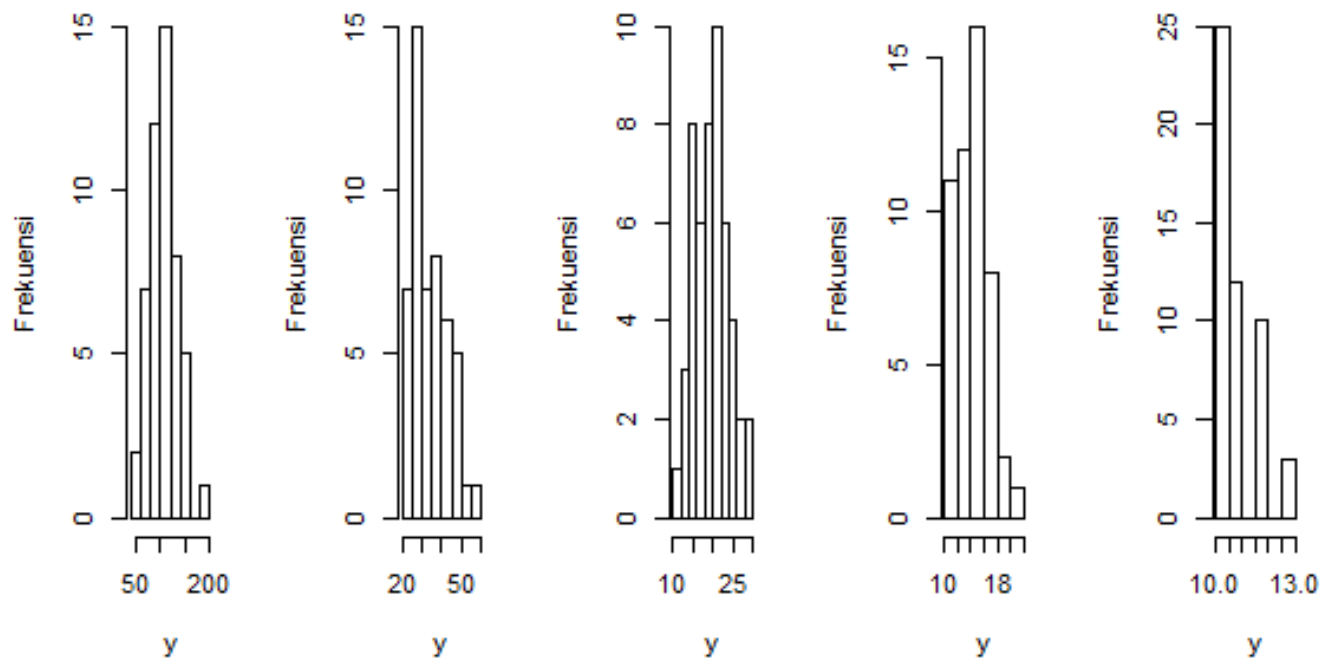

(a) $p=0.1$

(b) $p=0.3$

(c) $p=0.5$

(d) $p=0.7$

(e) $p=0.9$

Gambar 2: Histogram data pada $n=50$ dengan $(a) p=0.1,(b) p=$ $0.3,(c) p=0.5,(d) p=0.7$, dan $(e) p=0.9$ 

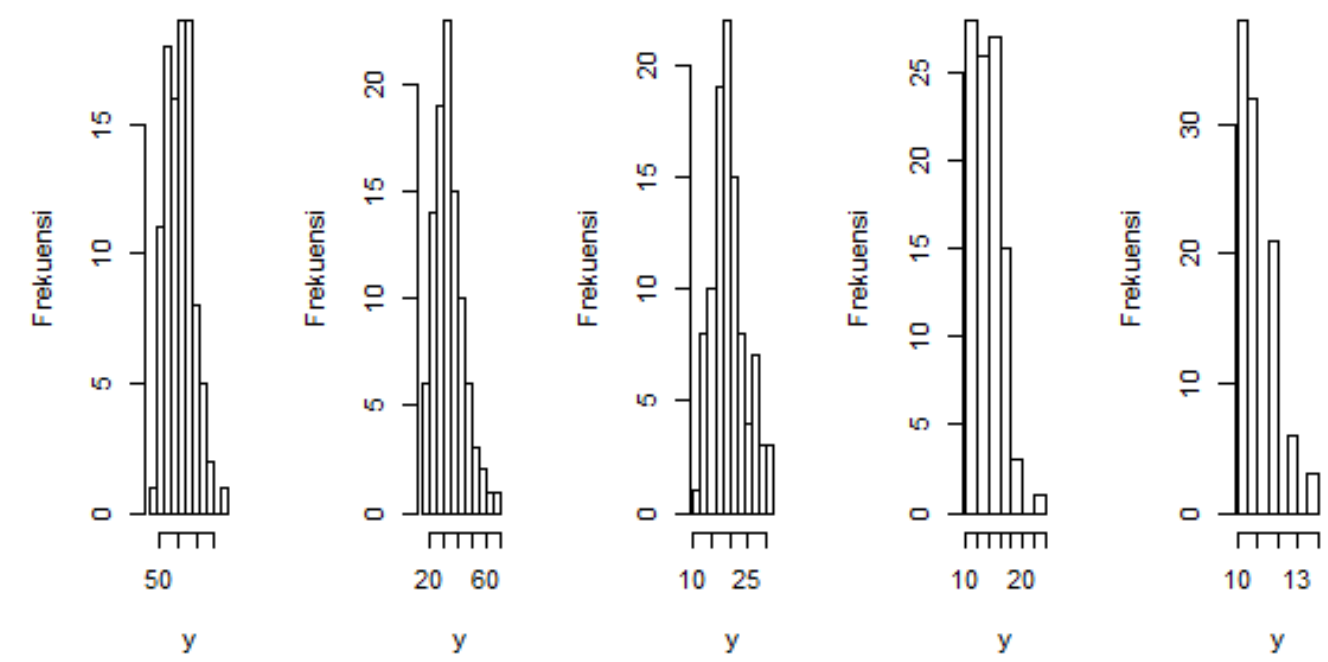

(a) $p=0.1$

(b) $p=0.3$

(c) $p=0.5$

(d) $p=0.7$

(e) $p=0.9$

Gambar 3: Histogram data pada $n=100$ dengan $(a) p=0.1,(b) p=$ $0.3,(c) p=0.5,(d) p=0.7$, dan $(e) p=0.9$

Eksplorasi pada data simulasi ditunjukkan dengan histogram Gambar 1, 2 dan 3 untuk mengetahui kondisi data yang dibangkitkan sebaran binomial negatif pada setiap ukuran contoh 10,50 dan 100 dengan $\boldsymbol{p}(0.1,0.3,0.5,0.7$ dan 0.9$)$. Ketiga gambar menunjukkan kondisi yang sama yakni ketika data dengan $p=0.1$ dan 0.3 memiliki interval data (range) sangat besar yakni antara 20-100. Hal ini mengindikasikan bahwa variasi dari data cukup besar. Penurunan nilai $p$ pada saat $p=0.5,0.7$ dan 0.9 mengalami perubahan interval data yakni antara 3-10 yang mengindikasikan bahwa variasi dari data kecil.

Hasil perhitungan matematis VMR pada Tabel 1 menunjukkan bahwa perubahan nilai VMR dipengaruhi pula variansi pada data. VMR pada sebaran binomial negatif mempunyai nilai variansi yang lebih besar. Maka, pada data dengan $p=0.1$ dan 0.3 memiliki variansi yang sangat besar dibandingkan yang lainnya. Kondisi pada data dengan $p=0.1$ dan 0.3 diduga merupakan sebaran binomial negatif yang memiliki nilai variansi lebih besar daripada rata-ratanya.

\subsection{Pengujian Kecocokan Sebaran}

Eksplorasi pada data simulasi dengan menggunakan histogram ketika $p=0.1$ dan 0.3 menunjukkan adanya dugaan sebaran binomial negatif, sehingga diperlukan pengujian terhadap data tersebut. Pengujian berupa uji khi-kuadrat untuk mengetahui kecocokan data terhadap peluang sebaran tertentu. Pengujian dilakukan terhadap tiga jenis sebaran data cacah yakni binomial negatif, poisson dan binomial dengan hipotesis sebagai berikut:

$H_{0}$ : data mengikuti sebaran tertentu

$H_{1}$ : data memiliki sebaran lainnya

Hasil uji khi-kuadrat dengan dengan taraf nyata $5 \%$ pada data bangkitan pada setiap kondisi ditunjukkan pada Tabel 2. 
Tabel 2: $p_{\text {value }}$ hasil uji kecocokan sebaran

\begin{tabular}{ccccc}
\hline$n$ & $p$ & Uji Binomial Negatif & Uji Poisson & Uji Binomial \\
\hline & 0.1 & $0.5175^{*}$ & 0.0000 & 0.0000 \\
& 0.3 & $0.1363^{*}$ & 0.0017 & 0.0000 \\
10 & 0.5 & $0.3917^{*}$ & $0.6932^{*}$ & $0.5244^{*}$ \\
& 0.7 & 0.0249 & 0.0808 & $0.1591^{*}$ \\
& 0.9 & 0.0024 & 0.0101 & 0.0262 \\
& & & & \\
& 0.1 & $0.7580^{*}$ & 0.0000 & 0.0000 \\
50 & 0.3 & $0.0950^{*}$ & 0.0000 & 0.0000 \\
& 0.5 & $0.9450^{*}$ & $0.9840^{*}$ & $0.1004^{*}$ \\
& 0.7 & 0.0230 & 0.0492 & $0.3165^{*}$ \\
& 0.9 & 0.0000 & 0.0000 & 0.0005 \\
& & & & \\
& 0.1 & $0.3141^{*}$ & 0.0000 & 0.0000 \\
100 & 0.3 & $0.2766^{*}$ & 0.0000 & 0.0000 \\
& 0.5 & $0.1034^{*}$ & $0.1484^{*}$ & 0.0213 \\
& 0.7 & 0.0070 & 0.0170 & $0.1156^{*}$ \\
& 0.9 & 0.0000 & 0.0000 & 0.0000 \\
\hline
\end{tabular}

Keterangan: *signifikan pada taraf nyata 5\% (data mengikuti sebaran yang diuji)

Hasil uji kecocokan data menunjukkan terdapat perubahan sebaran pada data yang telah dibangkitkan. Hasil uji kecocokan data menunjukkan perubahan parameter $p$ mempengaruhi pola sebaran data. Pada parameter $p=0.1$ dan 0.3 menunjukkan hasil bahwa data menyebar binomial negatif. Ketika parameter $p=0.5$ menyatakan bahwa pada ketiga uji menerima $H_{0}$. Hal ini mengindikasikan bahwa data dapat dikatakan menyebar binomial, poisson dan binomial negatif. Meskipun demikian, berdasarkan nilai $p_{\text {value }}$ saat parameter $p=0.5$ maka kecenderungan data lebih kuat menyebar poisson. Hal ini menunjukkan sebaran binomial negatif dapat mengalami pergeseran pola sebaran pada kondisi tertentu.

Selanjutnya saat $p=0.7$ menunjukkan hasil bahwa data menyebar binomial. Saat parameter $p=0.9$ menyatakan bahwa pada ketiga uji menolak $H_{0}$ yang mengindikasikan bahwa data tidak menyebar binomial, poisson maupun binomial negatif. Hal ini terjadi sebab ketika parameter $p=0.9$ menunjukkan sebuah keadaan menuju kepastian karena nilai $p$ mendekati 1 . Sehingga, kondisi tersebut tidak dapat didefinisikan menuju sebaran tertentu. Ringkasan hasil pengujian pada Tabel 2 sesuai dengan pendugaan sebaran berdasarkan pada eksplorasi data dengan histogram sebelumnya.

\subsection{Karakteristik Data Berdasarkan Nilai VMR}

Hasil pengujian khi-kuadrat dan eksplorasi histogram data simulasi menunjukkan adanya pengaruh parameter nilai $\boldsymbol{p}$ terhadap pola sebaran data cacah yang dibangkitkan. Selain pengujian pada data akan dilihat pula nilai VMR atau rasio ragam dan nilai tengahnya. VMR yang bernilai lebih besar dari satu maka dikatakan bahwa data mengikuti pola sebaran binomial negatif (overdispersi), sedangkan VMR dengan nilai lebih kecil dari satu mengindikasikan pola sebarannya binomial (underdispersi) dan ketika VMR nilainya sama dengan satu menunjukkan bahwa data memiliki pola 
sebaran Poisson (equidispersi). Berdasarkan data cacah yang telah dibangkitkan maka dihitung rata-rata nilai VMR untuk setiap kondisi ditunjukkan pada Tabel 3.

Tabel 3: Rata-rata nilai VMR berdasarkan kombinasi parameter $p$ dan $n$

\begin{tabular}{rrrrrr}
\hline$n$ & $p=0.1$ & $p=0.3$ & $p=0.5$ & $p=0.7$ & \multicolumn{1}{c}{$p=0.9$} \\
\hline & 4.490346 & 2.061138 & 1.039546 & 0.354075 & 0.087448 \\
8.689436 & 2.217704 & 0.874193 & 0.444827 & 0.10261 \\
& 8.606622 & 2.253127 & 0.959645 & 0.475213 & 0.117065 \\
& 8.053897 & 2.351807 & 1.011816 & 0.431552 & 0.11987 \\
10 & 8.877976 & 2.325667 & 0.879573 & 0.412596 & 0.106321 \\
& 8.97792 & 2.408126 & 0.995282 & 0.441023 & 0.103907 \\
& 8.354744 & 2.104199 & 0.881446 & 0.434319 & 0.117699 \\
9.493678 & 2.25199 & 0.985194 & 0.402851 & 0.111171 \\
9.798019 & 2.295839 & 0.945764 & 0.418084 & 0.107502 \\
8.920175 & 2.404042 & 0.955523 & 0.425002 & 0.115372 \\
& & & & & \\
8.686491 & 2.43858 & 1.026388 & 0.398082 & 0.111404 \\
8.722363 & 2.318736 & 0.989723 & 0.427644 & 0.109966 \\
8.758978 & 2.29368 & 0.999009 & 0.428204 & 0.10876 \\
8.483538 & 2.305857 & 1.023098 & 0.443377 & 0.112616 \\
9.121957 & 2.33629 & 0.971786 & 0.431342 & 0.110053 \\
8.849345 & 2.326725 & 0.974937 & 0.431342 & 0.10932 \\
8.705424 & 2.352953 & 0.968479 & 0.419085 & 0.108586 \\
9.222909 & 2.379881 & 1.01317 & 0.434227 & 0.112361 \\
9.301736 & 2.375819 & 1.008841 & 0.426894 & 0.110959 \\
8.715854 & 2.367847 & 0.978098 & 0.435601 & 0.110933 \\
8.995548 & 2.315431 & 1.004043 & 0.420426 & 0.112323 \\
& & & & & \\
8.792833 & 2.248518 & 0.970835 & 0.397453 & 0.110758 \\
9.190425 & 2.362961 & 1.006354 & 0.421214 & 0.108621 \\
9.009174 & 2.344101 & 1.008058 & 0.425447 & 0.111271 \\
9.050414 & 2.198693 & 1.002234 & 0.426471 & 0.111442 \\
8.881311 & 2.318688 & 1.006894 & 0.427447 & 0.111243 \\
9.142593 & 2.398925 & 0.979298 & 0.430443 & 0.112989 \\
9.017383 & 2.351341 & 1.01512 & 0.43273 & 0.111415 \\
9.143093 & 2.369958 & 1.000353 & 0.428041 & 0.110811 \\
8.978931 & 2.323795 & 0.993518 & 0.439459 & 0.109019 \\
8.944628 & 2.286712 & 1.012037 & 0.422731 & 0.107211 \\
9.154844 & 2.326578 & 0.997293 & 0.43488 & 0.111356 \\
\hline & & & & & \\
& & & &
\end{tabular}

Tabel 3 menunjukkan adanya perubahan nilai rata-rata VMR pada setiap ukuran contoh dan parameter nilai $\boldsymbol{p}$ yang terbagi menjadi 3 keadaan berdasarkan teori nilai VMR. Kondisi pertama yakni ketika nilai $p=0.1$ dan 0.3 menunjukkan rata-rata VMR 
lebih dari satu. Kondisi kedua saat $p=0.5$ menghasilkan rata-rata VMR mendekati satu. Kondisi ketiga yakni ketika nilai $p=0.7$ dan 0.9 rata-rata VMR kurang dari satu (menuju 0).

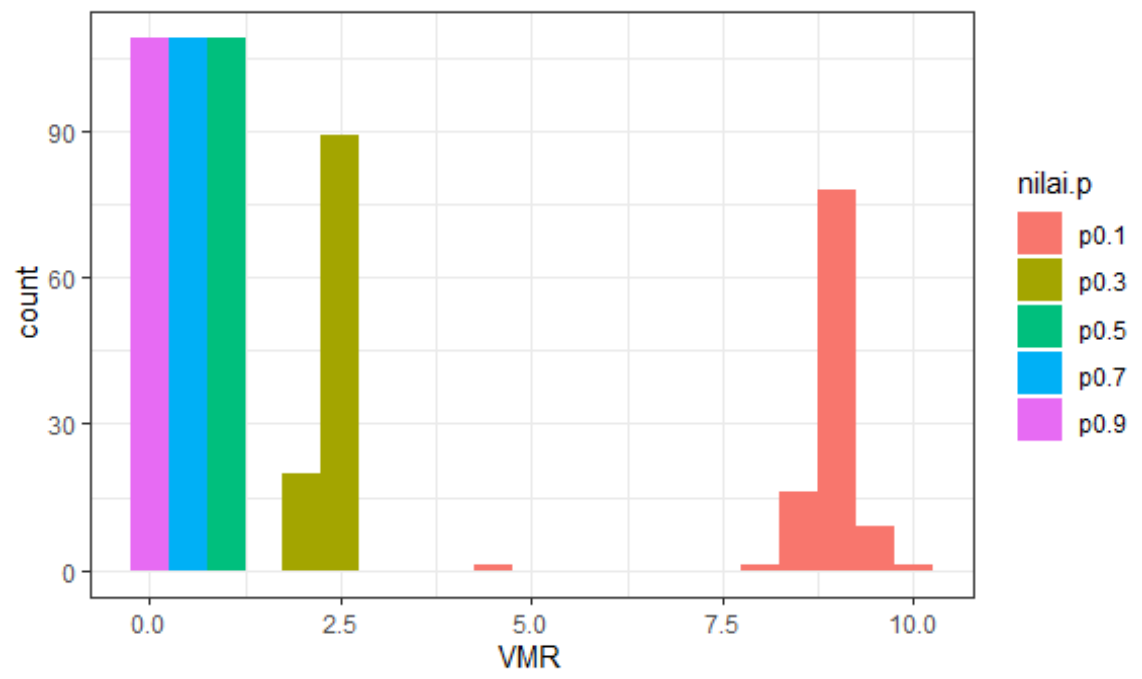

Gambar 4: Histogram frekuensi rata-rata VMR dengan $p=0.1,0.3,0.5,0.7$, dan 0.9

Perbandingan rata-rata nilai VMR setiap parameter $p$ dapat dilihat secara jelas pada Gambar 4. Rata-rata nilai VMR lebih besar dari 1 ketika parameter $p=0.1$ dan 0.3 , sedangkan saat nilai $p=0.5$ menunjukkan rata-rata nilai VMR mendekati 1 serta saat $p=0.7$ dan 0.9 rata-rata nilai VMR mendekati 0 . Hal ini menunjukkan bahwa data simulasi yang dibangkitkan sudah mengikuti sebaran binomial negatif, namun saat $p \geq$ 0.5 mulai terjadi perubahan sebaran data menuju sebaran Poisson dan binomial.

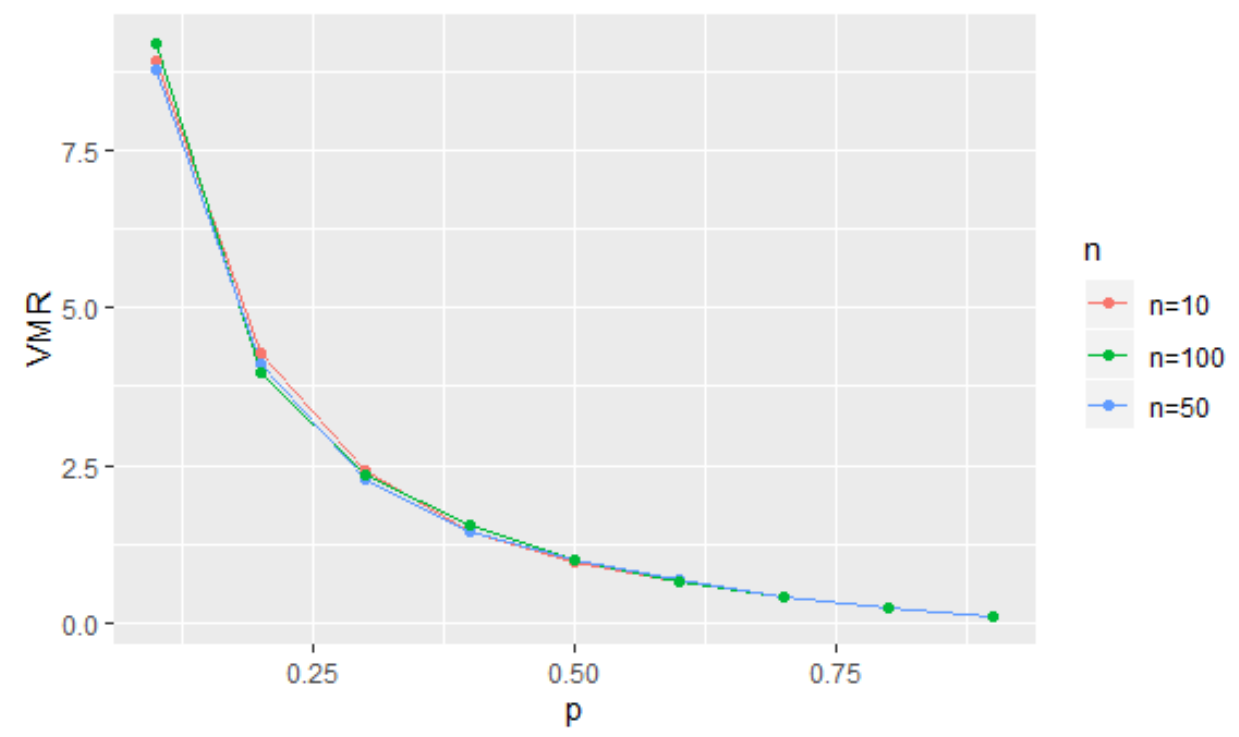

Gambar 5: Grafik rata-rata nilai VMR pada setiap ukuran sampel $n=10,50,100$

Gambar 5 memperlihatkan pada setiap ukuran contoh menunjukkan perubahan rata-rata nilai VMR yang semakin menurun seiring dengan semakin naiknya nilai $p$. 
Hal ini sesuai dengan rumus matematis pada sebaran binomial negatif $\left(V M R=\frac{1}{p}\right)$ yang menunjukkan bahwa nilai VMR berbanding terbalik dengan nilai $p$.

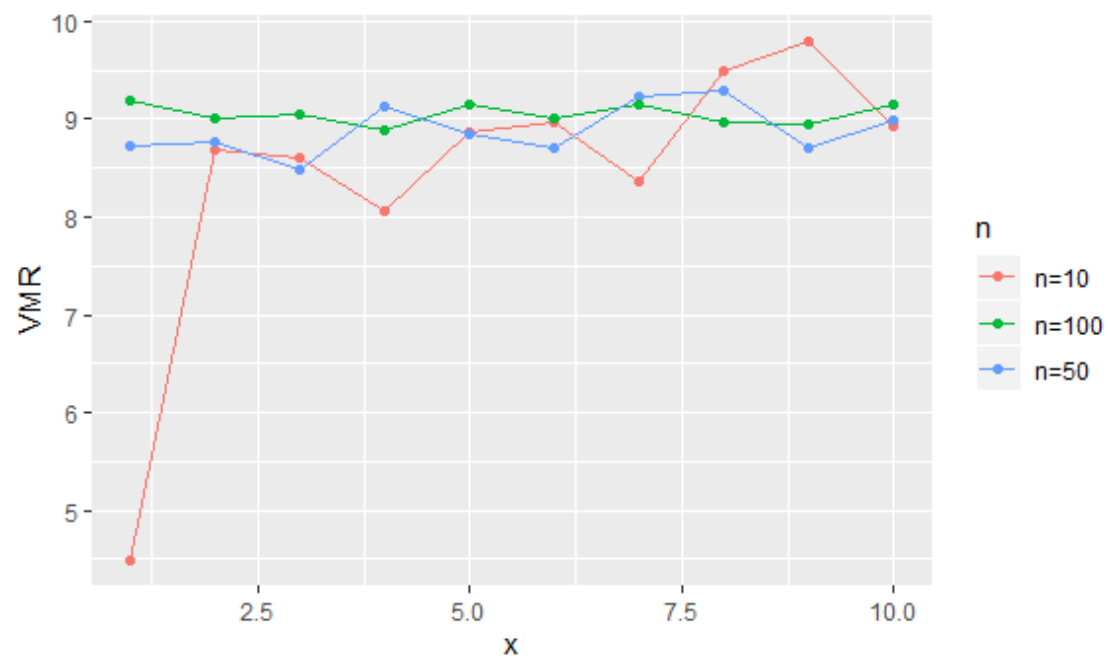

Gambar 6: Grafik rata-rata VMR saat $p=0.1$ untuk $n=10,50,100$

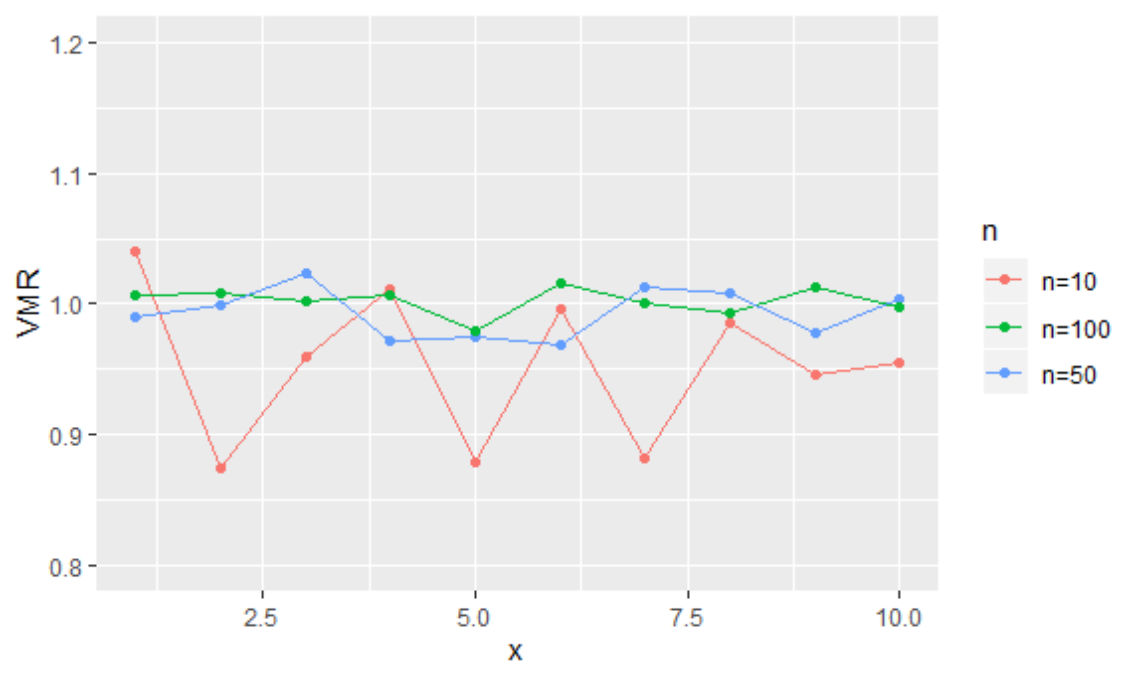

Gambar 7: Grafik rata-rata VMR saat $p=0.5$ untuk $n=10,50,100$

Ketiga plot pada Gambar 6, 7 dan 8 memperlihatkan pola yang sama yakni perubahan rata-rata nilai VMR semakin stabil seiring dengan ukuran contoh $n$ yang besar. Nilai VMR fluktuatif naik turun ketika ukuran contoh 10, sedangkan pada saat ukuran contoh 100, menunjukkan nilai VMR cenderung stabil. Hal ini mengindikasikan bahwa nilai VMR cenderung stabil seiring dengan besarnya ukuran contohnya.

Hasil eksplorasi data simulasi dan pengujian terhadap sebaran data menunjukkan kesimpulan yang sama pada teori perhitungan nilai VMR. Perhitungan nilai VMR menyatakan bahwa sebaran binomial negatif nilai VMR lebih besar dari 1 dan 
berbanding terbalik dengan parameter $\boldsymbol{p}$. Hal ini telah dibuktikan dari simulasi data yang dibangkitkan mengikuti sebaran binomial negatif.

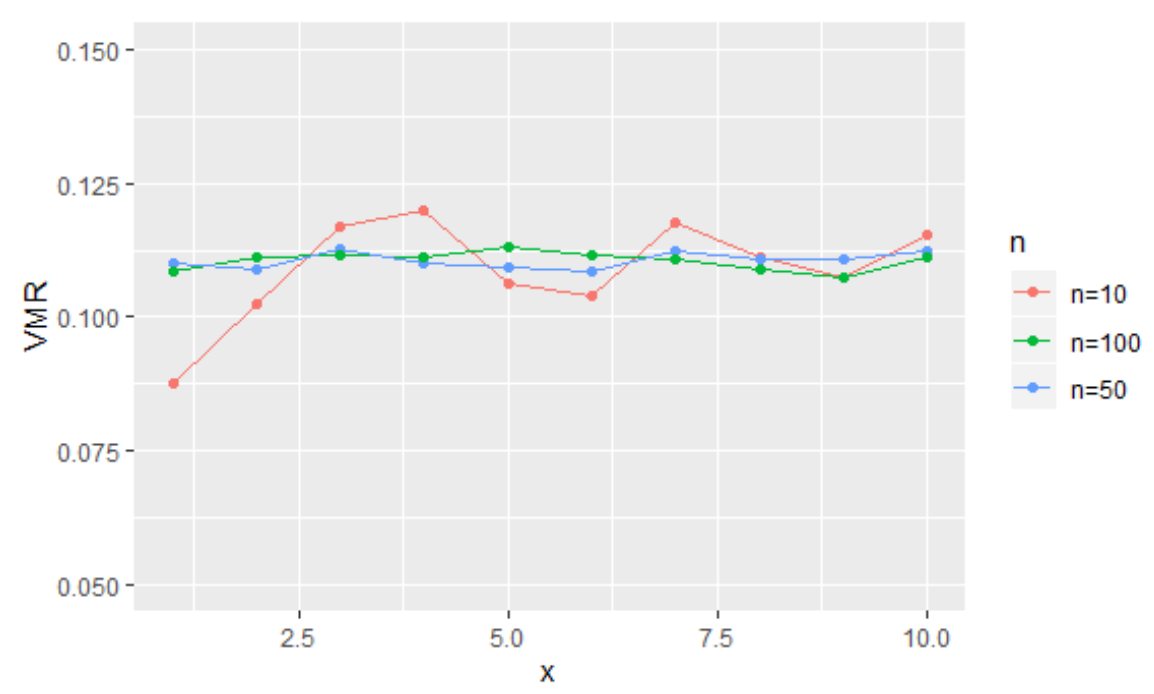

Gambar 8: Grafik rata-rata VMR saat $p=0.9$ untuk $n=10,50,100$

\section{Simpulan}

Kajian simulasi data sebaran binomial negatif dengan berbagai kondisi menunjukkan pola perubahan sebaran. Ketika nilai $p \geq 0.5$ mulai terjadi perubahan sebaran data menuju sebaran Poisson dan binomial. Rata-rata nilai VMR lebih besar dari 1 saat parameter $p=0.1$ dan 0.3 , sedangkan ketika nilai $p=0.5$ rata-rata nilai VMR mendekati 1 serta saat $p=0.7$ dan 0.9 rata-rata nilai VMR mendekati 0 . Sebaran binomial negatif mempunyai nilai VMR lebih besar dari 1 ketika parameter $p=0.1$ dan 0.3 dan berbanding terbalik dengan parameter $\boldsymbol{p}$. Hal ini sesuai dengan rumus matematis pada sebaran binomial negatif $(V M R=1 / p)$ yang menunjukkan bahwa nilai VMR akan semakin kecil ketika nilai $\boldsymbol{p}$ besar. Perubahan rata-rata nilai VMR semakin stabil seiring dengan semakin besarnya ukuran contoh. Perhitungan nilai VMR dapat dijadikan sebagai acuan untuk pendeteksian pola sebaran data cacah.

\section{Daftar Pustaka}

Ahdika, A. (2015). Distribution of The Difference of Two Independent Poisson Random Variables and Its Application to The Literate Population Data. JURNAL EKSAKTA, 15(1-2): 61-74. https://doi.org/10.20885/eksakta.vol14.iss1-2.art7

Baron, M. (2014). Probability and Statistics for Computer Scientists (2nd ed.). Boca Raton: CRC Press.

Casella, G., \& Berger, R. (2001). Statistical Inference (2nd ed.). Pacific Grove, CA: Duxbury Press. 
Hilbe, J. M. (2011). Negatif Binomial Regression (2nd ed.). New York: Cambridge University Press.

Hilbe, J. M. (2014). Modeling count data. New York, NY: Cambridge University Press.

Inuwa, P. D. (2013). A Critical Review of Some Properties and Applications of the Negative Binomial Distribution (NBD) and Its Relation to Other Probability Distributions. International Refereed Journal of Engineering and Science, 2(6): 3343.

Krebs, C. J. (2013). Ecological Methodology (2nd ed.). New York: Harper Collins Publisher.

Molla, D. T., \& Muniswamy, B. (2012). Power of Tests for Overdispersion Parameter in Negative Binomial Regression Model. IOSR Journal of Mathematics, 1(4): 29-36.

Walpole, R. E. (2007). Probability \& statistics for engineers \& scientists (8th ed). Upper Saddle River, NJ: Pearson Prentice Hall. 